\title{
RADIOGRAFIA DA CONSTITUIÇÃO
}

Em 5 de outubro de 1988 a Nação Brasileira conquistava uma nova Constituição. Em termos formais, era a sexta Constituição republicana, antecedida pela Carta Magna do período monárquico. Em verdade, nos hiatos em que se instauram Governos Provisórios, vigoraram textos com força equivalente às Cartas constitucionais. E, no curso de sua vigência, às Constituições se agregaram Atos Institucionais e Atos Complementares, a par de Emendas Constitucionais e Lei de Interpretação da Constituição monárquica. A perenidade não é, por certo, uma característica de nossas Cartas Magnas.

O sentido simbólico de uma Lei Maior, que sobrepaira a estrutura social, como garantia de normalidade da ordem jurídica, inspira a mística de um Estado formal, na expectativa de uma justa organização da sociedade. Pressupõe - a contrário de nossa vivência - a sacralidade de um documento estável no tempo e no conteúdo.

A Assembléia Constituinte se realizou como a ressurreição do sistema democrático, após uma fase de concentração de poderes e de limitação de direitos. Convergiram, no curso de seus trabalhos, aspirações de justiça social e reclamos de cidadania. Correntes reivindicatórias de diversa origem, de certo modo contraditórias, dilataram o teor da nova Constituição, distribuída em 245 artigos da parte permanente e outras 70 Disposições Transitórias. O enunciado de direitos fundamentais contido no artigo $5^{\circ}$ desdobra-se em 77 incisos. Os direitos dos trabalhadores, descritos no artigo $7^{\circ}$ são enumerados em 34 itens. A Ordem Econômica e Financeira, distribuída em quatro capítulos, abrange 23 artigos e a Ordem Social, dividida em oito Capítulos e sete Seções, compreende um ıniverso de paz social, desde a Seguridade Social e a Educação, Cultura e Desportos, até o Meio Ambiente, a Família, a Criança, o Adolescente e o Idoso, para se completar com a proteção dos Índios.

Iria longe a estatística se nos detivéssemos a computar os numerosos parágrafos, alíneas e números em que se minudenciam os comandos constitucionais.

A Constituição brasileira de 1988 é, salvo engano, a única Constituição promulgada com um prefácio. Na euforia do dever cumprido, o Presidente da Assembléia Constituinte fez preceder a divulgação do novo texto de um hino à Constituição Co- 
ragem, ou Constituição Cidadã, na qual estariam redimidos os pecados do autoritarismo.

Estuário de anseios de redenção nacional, a nova Constituição - dissemos em outra oportunidade - antes era de dar do que de exigir. Era, em duplo sentido, uma Constituição promissora. As promessas de uma ordem mais justa, se alcançadas, superariam a marginalização da parte carente e desamparada.

Pela latitude ampla de suas disposições, muitas delas não se realizavam de imediato. Várias de suas conquistas ficavam pendentes de elaboração de leis ordinárias ou complementares. Eram normas de eficácia contida, que a inércia do legislador tornava inoperantes.

Em publicação oficial, editada em 1989 pelo Ministério da Justiça, arrolavam-se 256 preceitos constitucionais que expressamente exigiam complementação legal, além de 87 outros que tacitamente impunham a exigência de lei reguladora.

Se, em certos casos, a existência de leis anteriores à Constituição, com ela compatíveis, a vigorar pelo princípio da recepção, suprimia temporariamente o vácuo, certamente a inovação constitucional reclamava lei nova, no sentido de atualização do direito ordinário.

Por este motivo, não poucas das aparentes conquistas continuam a ser ilusões constitucionais, na acepção de que falava MARX: acenos de solução com os quais os políticos procuram quitar promissórias eleitorais.

\section{II}

A Constituição de 1988 teve, de certa forma, como paradigma os modelos da Constituição portuguesa de 1976 e da Constituição espanhola de 1978. Ambas sucediam, como no caso brasileiro, a um período autoritário, em que o princípio da Ordem se sobrepunha ao sentido da Justiça.

A Constituição espanhola evoluiu, na construção da doutrina e dos tribunais, consolidando a essência de seus fundamentos. E a Constituição portuguesa, em suas revisões sucessivas - em 1982 e 1989 - eliminou os excessos de sua concepção primitiva.

O nosso legislador constituinte foi além. Na consciência de imperfeições e incertezas do novo Estatuto, no qual a busca do consenso perturbava a harmonia e clareza de seus comandos, de logo antecipou, após um qüinqüênio de vigência, a perspectiva de uma revisão constitucional, purificadora de equívocos e lacunas, sensível à experiência acumulada no quotidiano de sua aplicação.

Mal se aproximava, porém, o termo inicial da revisão constitucional e se esboçaram interpretações limitativas de sua abrangência. Alguns pretenderam filiar o âmbito da revisão ao resultado do plebiscito previsto no artigo $2^{\circ}$ do Ato das Disposições Transitórias. A título de uma curiosa exegese topográfica, a revisão estabelecida no artigo imediatamente tão-somente contemplaria os efeitos da corsulta sobre a forma e o regime de governo. 
Vencida esta interpretação restritiva, procurou-se ver no artigo $60, \S 4^{2}$, a intangibilidade das chamadas cláusulas pétreas, inatingíveis no processo ordinário de emenda constitucional. Em verdade, a proibição, que ali se prescreve, interdita propostas de emendas que importem abolição dos princípios enumerados, não impedindo possam ser aperfeiçoados em seu conteúdo.

Certo é que as resistências políticas e a abstenção continuada do Congresso no exercício de seus deveres conduzem o processo de revisão.constitucional à morte por inanição. Apenas um ato de revisão se consumou até agora, quando se torna próximo o vencimento do prazo deliberativo, que, na tentativa de salvação, se pretende transferir para o futuro Congresso, a ser revitalizado pelas eleições gerais que se aproximam.

A estrutura constitucional está a merecer avaliação mais profunda.

A distribuição das fontes de receita ampliou e fortaleceu a economia dos Estados e Municípios, sem que, ao mesmo tempo, fosse a União aliviada de obrigações e encargos.

O sistema eleitoral continua a favorecer a multiplicidade de partidos e praticamente eliminou a regra da fidelidade partidária.

A Ordem Econômica permanece na ambigüidade entre monopólios e oligopólios e a afirmação solene da liberdade da iniciativa privada.

A letra da Constituição menciona 83 vezes o vocábulo direito, para não aludir a concessão de garantias, vantagens ou benefícios.

De outra parte, é sóbria na enunciação de deveres, apenas referidos 19 vezes, sendo que 11 são deveres do Estado em benefício do indivíduo.

A todos estes desafios não corresponde a atividade congressual de revisão constitucional, que a reiterada falta de quórum deliberativo condena à improdutividade.

\section{III}

As Constituições estaduais que sucederam ao parâmetro federal mais ainda se esmeraram em ampliar direitos e vantagens, ultrapassando em muitos casos a latitude de sua competência. Não há melhor exemplo de tais paradigmas generosos do que o preceito da Constituição baiana que assegura aos servidores públicos estaduais fornecimento de uma refeição diária de chocolate, possivelmente como estímulo ao consumo do cacau.

A inobservância de normas federais obrigatórias levaram à multiplicidade de ações de inconstitucionalidade que sobrecarregam a pauta do Supremo Tribunal $\mathrm{Fe}$ deral, chamado a decidir por duas vezes: no pedido de liminar suspensiva das disposições impugnadas e no julgamento final do mérito da pretensão.

\section{IV}

A Constituição de 1988 enriqueceu o elenco de remédios processuais que permitem a garantia de direitos fundamentais e cuidam de assegurar o efetivo acesso às normas programáticas. 
O mandado de segurança, nascido com a Constituição de 1946 para obstar lesão a direito líquido e certo, ofendido por ilegalidade ou abuso de poder, adquire categoria nova, que ultrapassa o âmbito individual.

Aos partidos políticos como às organizações sindicais ou associações de classe em funcionamento há pelo menos um ano é atribuída legitimidade para, em defesa do interesse legítimo de seus membros ou associados, propor mandado de segurança coletivo, que a todos venha a beneficiar.

A ação popular, franqueada a qualquer cidadão para anular ato lesivo ao patrimônio público, passa a se estender, igualmente, à defesa da moralidade administrativa, ao meio ambiente e ao patrimônio histórico e cultural.

Ainda aqui inspirada na Constituição portuguesa, é instituída a ação de inconstitucionalidade por omissão, facultando-se ao Supremo Tribunal Federal, diante da ausência de medida que torne efetiva norma constitucional, notificar o Poder competente para o suprimento da inércia. E se esta for de órgão administrativo, assinandolhe prazo de 30 dias para agir.

Com a Emenda Constitucional n. 3, de 1993, aditou-se, ainda, a figura da ação declaratória de constitucionalidade, que permite firmar, com teor normativo, a interpretação de norma constitucional de interesse geral.

É, contudo, em dois novos institutos processuais que se inaugura a amplitude de proteção a direitos e liberdades fundamentais.

O remédio do habeas data assegura o acesso a registros públicos e habilita o interessado a obter a devida retificação na via administrativa ou judicial.

A criatividade da Constituição de 1988 mais se destaca no nascimento de um novo meio de ação, o mandado de injunção, previsto sempre que a falta de norma regulamentadora venha a tornar inviável a realidade de direitos e liberdades constitucionais e de prerrogativas inerentes à nacionalidade, à soberania popular e à cidadania.

Na ausência de lei que tenha regulado a matéria, a prestação jurisdicional não terá caráter satisfativo, editando solução para o caso concreto.

A maioria do Supremo Tribunal Federal, nada obstante respeitáveis votos vencidos, continua fiel ao entendimento de que a concessão da medida não deve ir além da comunicação ao Poder Legislativo sobre a necessidade de editar a lei faltante.

Perante a notoriedade da inércia de Congresso, começa, porém, a evoluir a jurisprudência em termos mais objetivos.

Em mandado de injunção que apreciava o favor de isenção a entidades beneficentes, a Corte Suprema fixou o prazo de seis meses para a ação legislativa (Mandado de Injunção n. 232 (RDA-i 88: 1.55 ).

Em outro caso, em que a mora congressual impedia a militares anistiados o exercício constitucional, marcou-se o prazo de 60 dias para a elaboração da lei, findo o qual se declarava o direito à reparação financeira (Mandado de Injunção n. $285-$ RDA 185/204).

Em decisão mais recente, o Supremo Tribunal Federal acolheu a pretensão de sindicato de classe no sentido de não ser obrigado ao pagamento de juros superiores a $12 \%$ ao ano. 
Mantendo, embora, a jurisprudência de que a eficácia do limite constitucional de juros reais depende da edição de lei complementar, a maioria acompanhou o voto do Relator, acatando parcialınente o pedido, fixando prazo de 120 dias para a ação do Congresso e admitindo, em princípio, a responsabilidade do Estado pela continuidade da mora legislativa.

\section{V}

Uma última palavra sobre uma instituição constitucional que se fortaleceu perante a continuada retração do Poder Legislativo no elementar cumprimento de seus deveres de fazer a lei.

Prevê a Constituição que, em caso de urgência e relevante interesse público, é facultado baixar Medidas Provisórias, com força de lei, cumprindo ao Congresso Nacional, no prazo de 30 dias, deliberar sobre a conversão ou recusa da medida excepcional.

A Medida Provisória sucedeu ao sistema do Decreto-lei, característico do regime constitucional anterior.

Pressupõe a criação constitucional que, emitida a Medida Provisória, não se omitirá o Congresso na oportuna apreciação da norma transitória, a perecer a curto prazo.

A realidade política trouxe, porém, à excepcionalidade do remédio a progressiva instauração de um processo anômalo, que vem impondo a múltipla prorrogação de Medidas Provisórias que se sucedem, mês a mês, enquanto perdura a omissão legislativa.

A estatística anual revela o emprego abusivo do procedimento. Em 1988 foram editadas 24 Medidas Provisórias (as 9 primeiras fruto da conversão de decretos-leis anteriores, como disposto no art. $25, \S 2^{\circ}$ do ADCT); em 1989 foram baixadas outras 103; em 1990 o número elevou-se a 163; a crise política de 1991 e 1992 reduziu, respectivamente, a 11 e 10 o total de novas Medidas Provisórias. Voltou a acelerar-se o ritmo em 1993, com 96 Medidas Provisórias e, nos seis primeiros meses do ano em curso, outras 136 já foram emitidas, elevando a 490 o total de atos dessa natureza.

Mais acentuada se faz a tendência de renovação da mesma matéria em sucessivas Medidas Provisórias.

A Lei n. 8.666/93 sobre licitações e contratos administrativos foi objeto de sete Medidas Provisórias, até ser alterada pela Lei $\mathrm{n}^{2} 8.883 / 94$.

A Advocacia Geral da União, instituída no art. 131 da Constituição de 1988, teve sua organização regulada na Lei Complementar, n. 73, de 10 de fevereiro de 1993.

Como, todavia fosse incompleta, doze Medidas Provisórias - a primeira em 30 de junho de 1993 - se sucedem regulando o funcionamento do novo órgão, não sendo demasia supor que outras mais seguir-se-ão até que o Congresso venha a deliberar.

Até mesmo a reforma do sistema monetário nacional e suas graves repercussões na vida nacional sobrevivem na expedição de quatro Medidas Provisórias, sem que se possa alcançar o beneplácito final do Poder Legislativo. 
À margem do modelo ortodoxo traçado na Constituição, justifica-se uma forma imprevista de legislação paralela, com que o Executivo preenche o vazio do Congresso inoperante, perdido nas brumas de Brasília.

Este é o País real que, pelos interstícios da improvisação, elabora alternativas pragmáticas que, embora divorciadas da pureza dos princípios, conciliam a dogmática da Constituição com a realidade da vida social.

Confirma-se a ironia célebre de que as leis (e, no caso, a Constituição), tal como na experiência dos sexos, tornam-se fecundas, quando violadas. 